\title{
A linguistic landscape of the central business district of Accra
}

\section{Jemima Asabea Anderson', John Franklin Wiredu', Gladys Nyarko Ansah ${ }^{3}$, George Frimpong-Kodie ${ }^{4}$, Elizabeth Orfson-Offei ${ }^{5}$ and Dennis Boamah-Boateng ${ }^{6}$}

\author{
${ }^{1}$ Senior Lecturer, ${ }^{2}$ Associate Professor, ${ }^{3}$ Senior Lecturer, ${ }^{4}$ \\ Lecturer, ${ }^{5}$ Lecturer, ${ }^{6}$ Student Researcher \\ Department of English \\ University of Ghana
}

Corresponding author's e-mail: janderson@ug.edu.gh

Submitted: June 10, 2020/ Accepted: October 17, 2020 / Published: December 30, 2020

\begin{abstract}
Using the mixed method research approach, this study investigated the linguistic landscape of the central business district of Accra, Ghana. The study employed both the Ethnolinguistic Vitality Theory (EV) and the Place Semiotics Theory to explore the types of signage displayed by shop owners in the Makola market, the languages used on these signs, the dominant language(s) on the signs and how the use of language reflects the ethnolinguistic vitality of the local languages used in Accra. The findings present a very busy linguistic landscape where shop owners use the names of their companies and the products they sell as a marketing strategy through a variety of modes including signboards, billboards, taglines, and signposts to attract customers. There was also a preponderance of English in the linguistic landscape of Accra, which establishes English as a powerful tool for interethnic communication and national integration, giving an implicit impression of low vitality of indigenous languages in the space.
\end{abstract}

Keywords: Linguistic landscape, ethnolinguistic vitality, Accra, multilingualism, Ghana, signage

Legon Journal of the Humanities 31.1 (2020) 


\section{Introduction}

The language of a people gives them an identity. Similarly, the study of the language of a group of people, most specifically how they use their language, provides researchers with numerous interesting tools. The spoken or written language of a people when studied can reveal many things about those people. When it comes to written language, it is traditional to think about books and other handwritten or typed materials. Another aspect of written language is what is seen in the public space: on road signs, street names, names of buildings, billboards, etc. In every area of public space one decides to examine, one is bound to find these linguistic objects. The study of such linguistic objects within a specific public space has been described by some researchers in sociolinguistics as a study of the 'linguistic landscape' of that particular space. According to Landry and Bourhis (1997), "The language of public road signs, advertising billboards, street names, place names, commercial shop signs, and public signs on government buildings combine to form the linguistic landscape of a given territory, region, or urban agglomeration." (p. 25)

The type of linguistic landscape identified in an area can help describe its sociolinguistic make-up. It can offer information about the different languages used in that area and reveal some issues about the language policy, status, role and even perception of the languages. This makes the study of linguistic landscape in bilingual and multilingual environments particularly interesting.

This current study is conducted in such a multilingual environment. It focuses on the linguistic landscape of the central business district of Accra, specifically the area referred to as Makola Market, to see what types of signage are displayed by shop owners, the languages used on these signs and what the use of languages say about the sociolinguistic environment that is Accra.

In an environment such as the city of Accra, where many languages are spoken, a study of this nature which focuses on 
written language is significant because it enables us to see the correlation between languages spoken and languages written. It also affords us an opportunity to determine how the use of language can reflect the status of these languages, the policies around these languages and how the people in the area feel about the use of these languages.

\section{The sociolinguistic profile of Accra}

Accra is the capital city of Ghana. It is located in the Greater Accra Region. As at 2012, Accra had an urban population of 4,010,054 (Ghana Statistical Service, 2012). The Ga people are the original indigenes of Accra. Their language, Ga, is spoken in the South-Eastern part of Ghana, in and around the capital, Accra. It is closely related to Dangme together with which it forms the Ga-Dangme branch of the Kwa language group. The 2010 census puts the number of Ga-Dangme speakers at 7.4\% of the total population of Ghana. Out of the two groups (Ga and Dangme), the Ga speakers are the minority.

Accra is the most urbanized city of Ghana. It is also the economic hub and the centre for government businesses. For these reasons, it attracts migrants from different parts of the country. Many Ghanaians from the rural areas migrate to this city in search of jobs and better living conditions. This has led to the current state in which there are more immigrants than the native Ga-speaking people in Accra. The majority of the immigrants are native Akan speakers (percentage of native Ga in Accra is $18.9 \%$ as against Akan which is 39.8\% (Essegbey, 2009, p. 120). This could be as a result of about $70 \%$ of the population of Ghana speaking Akan either as first or second language (Dako \& Quarcoo, 2017, p. 21), while the 2010 Population and Housing Census provides $47.5 \%$ as the total percentage of Ghanaians who are native Akan speakers.

Apart from Akan and Ga, other indigenous Ghanaian languages spoken in Accra are Ewe, and a number of languages from the northern parts of Ghana including Dagbani, Buli, 
Dagaare, Kokomba, Kasem and Frafra. Other immigrants from neighbouring countries such as Togo, Benin, Burkina Faso and Nigeria can be found in Ghana. These foreigners have come to settle in the capital to work, as a result of intermarriages, nationalization and to attend the numerous educational institutions, particularly universities in Accra. All these people have come with their languages: French, Yoruba, Igbo, etc.

Several languages spoken by non-African migrants can also be found in Accra. For instance, there is a growing number of Lebanese and Chinese speakers residing in Accra. In addition to all these languages that are used here, the English language is also present. English was the language of the colonialists. It is the de facto official language of Ghana. It is the language of official government business, commerce, law, health and education (Curriculum Research Unit, Ghana Education Service, 1996). It enjoys a lot of privilege in Ghana as a whole and apart from its use in official circles, it is also a lingua franca for most people who may not have any of the indigenous languages in common.

Two kinds of Pidgin are also spoken in Accra. The first and older pidgin is the 'Ghanaian Pidgin English', also referred to as Town Pidgin (Dako, 2000) or uninstitutionalized /uneducated Pidgin (Huber, 1999). It is a variety of the more general West African Pidgin English. The second is the Student Pidgin (Dako, 2000), or institutional/educated Pidgin (Huber, 1999) which is used predominantly by students who were educated in secondary schools along the coast of Ghana. It is also used in the universities.

The current language situation in Accra is not a recent development. The literature shows that Accra has been multilingual from the very beginning. According to Dakubu (2009):

"The old 'Great Accra', as it was called in the European accounts, apparently had Ga, Akwamu and Obutu quarters, geographically delimited but clearly associated. Akwamu is a southern dialect 
Anderson, J.A., Wiredu, J.F., Ansah, G. N., Frimpong-Kodie, G., Orfson-Offie, E. \& Boamah-Boateng, D./Legon Journal of the Humanities Vol. 31.1 (2020)

of Akan, and Obutu was a Guang language, belonging to another branch of the Tano group and so closely related to Akan though far from mutually intelligible with it. It appears that $\mathrm{Ga}$ (or proto$\mathrm{Ga})$ was the language of the ruling clan(s), but that this community had incorporated numbers of other people and was closely associated with others who may not have been completely assimilated". (p. 24)

Dakubu's earlier publication in 1997 shows that the native Ga were found in the inner city of Accra (James Town, Ussher Town, Osu, La etc.) and therefore Ga was used predominantly there. This notwithstanding, "besides Ga, the major languages spoken were Akan, especially the variety known as Twi, and English, with smaller numbers speaking Dangme,Ewe and Hausa" (Dakubu, 1997, p. 53).

In the area Dakubu (ibid) labeled as 'Inner Surbubia' which includes Kantamanto, Korlewokong and Adabraka, we found the Ga population to be in minority. The majority of the people that were found there were the Dagombas, Nanumbas and Komkombas from northern Ghana; Ewe from the Volta Region; Akan; Yoruba and Igbo from Nigeria as well as Togolese and Beninoise. The main language used in these areas was Akan, and for that matter, the other language speakers had to acquire it as a second language, and also Ga, if they were not native $\mathrm{Ga}$ (Dakubu, 1997, p. 64). Those who had had some level of formal education also spoke English. There was again a strong presence of migrants from the north in Nima, New Town, Maamobi, Achimota and Mataheko. The majority were Dagaaba, Bulsa and Kusaasi. These people spoke their native languages but also had Akan, English, Hausa and $\mathrm{Ga}$ as second language, with Akan being the most common second language, followed by Hausa (Dakubu, 1997, p. 79).

It is obvious from the preceding discussion that Accra is a city bursting with a multitude of languages, though the 
major ones are Akan, English, Ga and Hausa. Akan speakers are in the majority, either as first or second language speakers; the $\mathrm{Ga}$ are the indigenes, though in the minority; while Hausa, which is restricted to the Zongo communities, is spoken mostly by migrants from the Northern part of Ghana (Ghana Statistical Service, 2012). Against this backdrop, it is therefore alluring to investigate how this multiplicity of languages is reflected on the linguistic landscape of this city.

\section{Research objectives}

This study has the following four principal objectives:

1. To examine the types of signage that are displayed by shop owners in the Makola market;

2. To examine the languages that are used on the signage;

3. To find out the dominant languages on the signs; and

4. To investigate whether or not the use of languages on the signage reflects the ethnolinguistic vitality of the indigenous language used in the city of Accra.

\section{Research questions}

1. What types of signage are displayed by shop owners in Makola market?

2. What languages are used on the signage?

3. Which language is dominant?

4. How does the use of languages on the signage reflect the ethnolinguistic vitality of the indigenous language use in the city of Accra?

\section{Literature review}

Over the years, a considerable attention has been given to linguistic landscape studies. A vast majority of these studies have been conducted in major multilingual speech communities. For example, linguistic landscape studies carried out by Backhaus (2007), Edelman (2010), Pavlenko (2010), Reyes (2014), Koschade (2016), and Said and Rohmah (2018) were in cities 
Anderson, J.A., Wiredu, J.F., Ansah, G. N., Frimpong-Kodie, G., Orfson-Offie, E. \& Boamah-Boateng, D./Legon Journal of the Humanities Vol. 31.1 (2020)

like Tokyo (Japan), Amsterdam and Friesland, Kyiv (Russia), Metro Manila (Philippines), Hahndorf (South Australia) and Andalusia respectively. Only a small number of studies (Kotze \& du Plessis, 2010; Plessis, 2012; Banda \& Hambaba, 2015; Loth, 2016) have paid attention to the linguistic landscape of rural areas.

One significant result that has been consistent in the majority of these studies (Reyes, 2014; Shibliyev, 2014; Koschade, 2016; Loth, 2016; Zimny, 2017; Lusekelo \& Alphonce, 2018) is the preponderance of English in the linguistic landscape of both rural and urban areas. In their study, Lusekelo and Alphonce (2018) examined the state of multilingualism in the linguistic landscape of billboards and shop-signs of urban areas in Tanzania. Both English and Kiswahili were identified as the dominant languages on the signs. However, despite the general view that Tanzania is a Kiswahili-speaking country, their study concluded that English plays a significant role on bilingual signposts than Kiswahili. According to the results of the study, Kiswahili dominates on the basis of word count, while English is given more prominence in terms of font colour and font size. The study also revealed a high frequency of English-only signs than monolingual signs in Kiswahili. A study by Zimny (2017) on the linguistic landscape of Windhoek's central business district in Namibia also revealed the prevalence of English on signage in Namibia, which is in contrast with the language policies of Namibia. Similarly, Akindele's (2011) study on the public signage in Gaborone, Botswana showed a dominant use of English in all the signage.

In a related study, Koschade (2018) examined the linguistic profile of Hahndorf and the factors that influence the linguistic landscape of the town. It is interesting to note that despite the predominance of German migrants in the city, English was dominant on all the eighty signs analysed. It was also reported that just like the results obtained by Reyes (2014), most of the monolingual signs were in English, while bilingual 
signs also had both English and German. Another important study, which highlights the global importance of English is Dixson's (2015) work on the linguistic landscape of Buffalo, New York. Results of the study indicated the presence of language ideologies, and despite the fact that Buffalo is dominated by Latinos, immigrants and refugees, the study concluded that one needs English to function in Buffalo.

Based on the assumption that drastic societal changes result in changes in the dominance of languages, Shibliyev (2014) examined the linguistic landscape of Post-Soviet Baku to find out if the official language policy of the town had the support of entrepreneurs. The findings of the study showed that English has taken over most of the functions enjoyed by Russian, which used to be the dominant language in Baku. The key implication drawn from this pivotal research is that English dominates not only the minor languages but also major languages such as Russian, emphasizing its role as a world language.

The concept of linguistic landscape had been criticized for its lack of a consistent methodology and theory. Nevertheless, as the scope of linguistic landscape expands to incorporate new areas of study, new methods and theories are introduced. Previous studies in linguistic landscape had been quantitative in nature as pictures of signage were collected and analyzed. Nevertheless, researchers like Spolsky (2009) and Shohamy and Gorter (2009) indicated the need to involve sign writers and consumers in such studies. For this reason, recent studies on linguistic landscape have embraced mixed methods, combining both qualitative and quantitative approaches. Thus, in addition to pictures of signage, a great number of these studies have adopted, interviews, questionnaires and other useful approaches to obtain data for their study.

In their study, for example, Said and Rohmah (2018) investigated the use of Arabic in the linguistic landscape of Andalusia. While the research extensively used pictures of signage as data, the researchers interviewed two informants to 
Anderson, J.A., Wiredu, J.F., Ansah, G. N., Frimpong-Kodie, G., Orfson-Offie, E. \& Boamah-Boateng, D./Legon Journal of the Humanities Vol. 31.1 (2020) obtain comprehensive knowledge of language use on the signage. Along the same lines, Edmund (2017) adopted ethnographic observation, interviews and socio-historical information in addition to the pictures of signs to do a linguistic landscape analysis of migration and assimilation in Cary, North Carolina.

Finally, to study the language practices in the linguistic landscape of some cities in Jordan, Alomoush (2015) adopted questionnaires and interviews, together with the pictures of signage he had taken. These sources of data were adopted because of the realization that minority languages were absent in the linguistic landscape of the cities, and the researcher was interested in finding out the cause of this. The findings of the study indicated that the absence of minority languages on the signage was due to the lack of parental and institutional assistance, small size of minority linguistic groups, migration and lack of ties with families and friends.

Theoretically, many researchers (Landry \& Bourhis, 1997; Yagmur \& Kroon, 2003; Fekede \& Gemechu, 2015) have adopted Giles et al.'s (1977) concept of ethnolinguistic landscape to determine the strength or otherwise of languages in speech communities and also determine the possibility of language maintenance or language death. Fekede and Gemechu (2015) relied on this theory to examine the ethnolinguistic vitality of languages in some selected towns in Oromia: Adama, Jimma, and Sabata. In addition to the pictures of signage they collected, they also conducted interviews with sign owners and residents of the towns. One significant finding in this research is that whereas most studies reported the dominance of English in the linguistic landscape of the towns or cities they investigate, the analysis of the data indicated a high ethnolinguistic vitality score for Amharic, followed by English, while Afan Oromo was found to be the least. The key implication of this finding is that English tends to dominate in areas with a colonial history.

Finally, Yagmur and Kroon (2003) adopted the ethnolinguistic vitality theory to examine the ethnolinguistic 
Anderson, J.A., Wiredu, J.F., Ansah, G. N., Frimpong-Kodie, G., Orfson-Offie, E. \& Boamah-Boateng, D./A linguistic landscape of the central business district of Accra

vitality perceptions and language revitalization in Bashkortostan. The findings indicated that both the peoples of Bashkir and Russia have high group-esteem which indicates a positive ethnolinguistic vitality.

Another significant theory that has been introduced into the study of linguistic landscape is the geosemiotics/place semiotics approach introduced by R. Scollon and S. Scollon (2003) which stipulates that the meanings of signs can be derived from their placement in a linguistic landscape. According to this theory, visual images obtain their meanings from where they have been positioned. In this regard, the selection of languages, the visual representation of languages and the position of languages on signs (whether placed at the top, middle or bottom) contribute to the meanings of signs. Employing this theory, Reyes (2014) studied the linguistic landscape of two major stations in Metro Manila, Philippines. The study reported the predominance of English and Filipino. However, English was found to be the preferred language over Filipino since there were more signs in English only than Filipino only. Another observation was that on bilingual signs that had both English and Filipino, there was a high preference for English, as English was highlighted by being positioned at the middle, top or left of the signs or being circled, underlined, or capitalized. The dominance of English on the signs was interpreted to suggest a positive attitude towards Americans. In other words, the positive attitude Filipinos have towards Americans has a great impact on their preference for English. This may be attributed to the fact that "English was introduced as part of the institutionalization of the public school system in the Philippines by the United States in 1901" (Reyes, 2014, p. 26).

It is worthy to mention that studies in linguistic landscape continue to grow in complexity as new methods and theories are consistently introduced. This really highlights the significance of this concept in multilingual studies. It is interesting to note that while studies in linguistic landscape have gained prominence in 
Anderson, J.A., Wiredu, J.F., Ansah, G. N., Frimpong-Kodie, G., Orfson-Offie, E. \& Boamah-Boateng, D./Legon Journal of the Humanities Vol. 31.1 (2020)

Europe, Asia, and America, only a few studies exist in Africa. In Africa, existing studies on linguistic landscape have produced results which are similar to those generated outside Africa. In almost all the studies in Africa, there is evidence of the overwhelming dominance of English in the linguistic landscape of the various cities, which is a reflection of the colonial history of Africa. It is therefore not surprising that Fekede and Gemechu's (2015) study in Ethiopia reported a high ethnolinguistic vitality score for Amharic which can be attributed to their lack of a colonial past. Studies in Africa have also shown a greater degree of complexity, as more innovative methodologies and theories are employed.

It is important to point out that many of the studies carried out in Africa have been done in South Africa (Loth, 2016), Namibia (Zimny, 2017), Nigeria (Adebola, 2017), Ethiopia (Fekede \& Gemechu, 2015), Botswana (Akindele, 2011), Tanzania (Lusekelo \& Alphonce, 2018) and few other African countries. Interestingly, such studies hardly exist in Ghana, despite their significance. The current study, therefore, attempts to fill the gap by exploring the linguistic landscape of Accra.

\section{Theoretical framework}

This research adopted the Ethnolinguistic Vitality Theory by Giles, Bourhis, and Taylor (1977), and the Place Semiotics Theory by Scollon and Scollon (2003) to answer the research questions.

\section{Ethnolinguistic vitality}

The Ethnolinguistic Vitality Theory (EV) is considered as a socio-psychological approach to the relationship between language and identity. According to Giles et. al. (1977), the vitality of an ethnolinguistic group refers to "that which makes a group likely to behave as a distinctive and active collective entity in intergroup situations" (p. 308). They explain that the ethnolinguistic vitality of a group comprises factors such as 
status, demography, institutional support and control. Status, according to them, refers to the social, economic, sociohistorical, and language status of a group both within and outside the community. Demography implies the population, distribution patterns, birth rate, patterns of immigration and emigration, and rate of mixed marriages of an ethnolinguistic group. Institutional support is determined by the formal and informal assistance that an ethnolinguistic group receives in institutions such as education, the mass media, government services, politics, education, culture, religion, and industry.

They assert that the vitality of a group can be described as low, medium or high depending on the strengths and weaknesses in each of these factors. Thus, groups with low vitality have the tendency to undergo linguistic assimilation. Conversely, those with high vitality possess distinctive characteristics in multilingual settings and they are likely to maintain their language. Fundamentally, the Ethnolinguistic Vitality theory is based on the premise that social identity and language behaviour have a mutual relationship. According to this theory, every society possesses some sociostructural variables which influence the ethnolinguistic vitality of groups that exist in that society, and these variables determine the survival of languages in a given community. In other words, they determine whether there would be assimilation, language loss or maintenance.

\section{Place Semiotics/Geosemiotics}

The Place Semiotics Theory was introduced by R. Scollon and S. Scollon (2003). According to this theory, the meanings of signs and symbols can be derived from their locations (where they are placed) in a linguistic landscape. According to them, code preference, inscription, and emplacement are the components of place semiotics. Code preferences refer to "how signs represent the geopolitical world through the choice of languages, their graphic representation, and their arrangement if more than one language is contained on a sign' (Backhaus 2007, 
Anderson, J.A., Wiredu, J.F., Ansah, G. N., Frimpong-Kodie, G., Orfson-Offie, E. \& Boamah-Boateng, D./Legon Journal of the Humanities Vol. 31.1 (2020)

p. 37). This implies that the position of a particular language on a bilingual or multilingual sign determines its preferential use and may indicate the importance of a particular language. The font style, font colour and other salient features of signs may also contribute to the preferential use of a language. Emplacement of signs concerns where the sign has been physically placed. These signs can appear in similar forms irrespective of the context (decontextualized), wrongly placed (transgressive) or they can derive their meanings from specific locations (situated).

\section{Methodology}

The study adopted both qualitative and quantitative approaches to investigate the linguistic landscape of signage at Makola, one of the biggest marketplaces in Ghana. The data for the study comprised 356 digital pictures of signage taken from the market. In order for the researchers to familiarize themselves with the landscape and to explore the different sites of the market, they conducted a study tour of the entire marketplace. Since Makola is a very huge marketplace, it is always overcrowded due to the hustle and bustle of both retailers and customers. This situation was an impediment to the collection of the data. To prevent this, the researchers decided to collect the data on early Sunday mornings ${ }^{1}$. This made the work of the researchers much easier since the market is less busy on Sundays, especially in the mornings. Most of the pictures were taken with Samsung Galaxy S4 phones, which have high pixels. It became necessary to take several shots of the same signage to ensure that all the pictures used for the study were clear enough for effective analysis.

The study focused on signs that had been displayed outside the shops. The signage that were considered included billboards, commercial signs, street signs, and other signage that have text on them. All those signs that had been placed inside the shops were ignored. Again, texts written on bottles and other products were not considered for the study. For superstitious

${ }^{1}$ On Sundays many shops do not operate and those that operate open later in the day. This is because many of the patrons and shop owners go to church on Sunday morning. 
reasons, some shop owners had refused to allow the researchers to take pictures of the signage of their shops. This is a problem which is normally encountered by a study of such nature. It is interesting to know that Edelman (2010) encountered a similar problem during a related study in the Netherlands, where some shop assistants prevented him from taking pictures in their shops.

Studies of linguistic landscapes can be classified into two, depending on the approach adopted for the study. There can be synchronic approach, which deals with signage at a particular location and in a particular era, and diachronic approach where the signage of an older period is compared with those in current times. There are a number of studies that have taken a diachronic approach in dealing with this type of work such as Pavlenko (2010) and Plessis (2012). However, the current paper adopts a synchronic perspective of the linguistic landscape. In other words, it deals with existing signage at the marketplace.

\section{Analysis \\ General description of signage}

Table 1 presents general information given on the signage in terms of the type of signage and a description of the product or service the signage displays. Generally, the signage can be grouped into three categories: company signage, product name signage and a blend of product and company name signage. Company signage are those that reflect names of stores, service providers and others which are not necessarily related to any product or brand. About $76 \%$ of the signage sampled belonged to this classification. Product names are signage that bear information on a particular product without recourse to a name of a company within the central business district. This classification formed about $21 \%$ of the total sample. The third classification of signage contained a blend of product and company names, representing about $11 \%$ of the total sample.

Information captured on the signage was from a wider

Legon Journal of the Humanities 31.1 (2020)

Page $\mid 14$ 
Anderson, J.A., Wiredu, J.F., Ansah, G. N., Frimpong-Kodie, G., Orfson-Offie, E. \& Boamah-Boateng, D./Legon Journal of the Humanities Vol. 31.1 (2020)

range of products and services which included information on the sale of hair and beauty products, sale of fashion items such as clothes, shoes and bags (15\%) and the sale of food items (7\%). In addition, there were signage that were based on health and pharmaceutical services, the sale of building materials and other financial services provided. The category labelled 'others' included signage that contained information related to educational and religious institutions, delivery services, public announcements, hardware stores and sport betting outlets. A thorough description of the information on the signage is given in Table 1 .

Table 1: Characteristics of signage

\begin{tabular}{lll}
\hline Variable & Frequency & Percentage \\
\hline Type of signage & & \\
Company signage & 135 & $76 \%$ \\
Product name & 21 & $12 \%$ \\
Blend of product and company name & 19 & $11 \%$ \\
Others & 3 & $2 \%$
\end{tabular}

\section{Product / Company description}

Hair and beauty products 28

$16 \%$

Clothing / Fabrics / Shoes / bags

26

$15 \%$

Food products / Service

Cosmetics

Phones / Accessories / Computers

11

$6 \%$

Financial Services

Health / Pharmaceuticals

10

$6 \%$

Electronic Appliance

9

$5 \%$

Building material

8

$4 \%$

Household equipment

6

$3 \%$

Babycare products

5

$3 \%$

Legon Journal of the Humanities 31.1 (2020) 
Mechanical Gadgets

Admin. Services

Jewellery

Public service

Stationery

Sundries

No description

Others

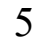

$3 \%$

4

$2 \%$

4

$2 \%$

3

$2 \%$

3

$2 \%$

3

$2 \%$

2

$1 \%$

16

\section{Language forms}

Although the Greater Accra region is the native home of the Gas, information obtained on the signage were given in two major languages: English and Akan. Dominant among these two languages was the signage that contained solely English language which constituted about 166 out of the 178 signage obtained (representing approximately 93\%). The other signage contained a blend of English and Akan languages, with only one signage containing solely the Akan language.

\section{Analysis of brand / company names}

Company name as well as brand name is as important as the product or service itself and hence owners of products, brands or companies take time in obtaining the desired name that fits the services they rendered. Table 2 presents a list of the ways in which the signage sampled gave the names to their brands and companies. The study found six name classifications which were mostly given in the English language. The largest classification was the group labelled as coinages as this category formed about $41 \%$ of the total sample collected. This category refers to names that are not necessarily names of individuals or groups but they are names that have been formed by either the combination of formal names or nicknames given to the owners of the company or product.

Figure 1 shows a signage that forms a name coined from 
Anderson, J.A., Wiredu, J.F., Ansah, G. N., Frimpong-Kodie, G., Orfson-Offie, E. \& Boamah-Boateng, D./Legon Journal of the Humanities Vol. 31.1 (2020) two different words new and lucky, giving an impression of luck and a sense of newness. The second panel of figure 1 displays a product that has the name coined to be kokosol. The first part of the name koko refers to the raw material from which the finished product (cooking oil) is made, which is coconut. The second part of the name denotes the nature of the product [a solution of coconut and other products]. Thus, the expanded name of kokosol could be coconut solution. Most product brands such as electrical appliances have these company name forms [e.g. Hisense Television, Binatone Fans etc.].

Table 2: Classifications based on brand / company names

\begin{tabular}{|l|l|l|}
\hline Classification & Frequency & Percentage \\
\hline Name of person & 30 & $16.9 \%$ \\
\hline Other & 6 & $3.4 \%$ \\
\hline Phrased & 35 & $19.7 \%$ \\
\hline Coined & 73 & $41.0 \%$ \\
\hline work detailed & 34 & $19.1 \%$ \\
\hline Total & 178 & 100.0 \\
\hline
\end{tabular}




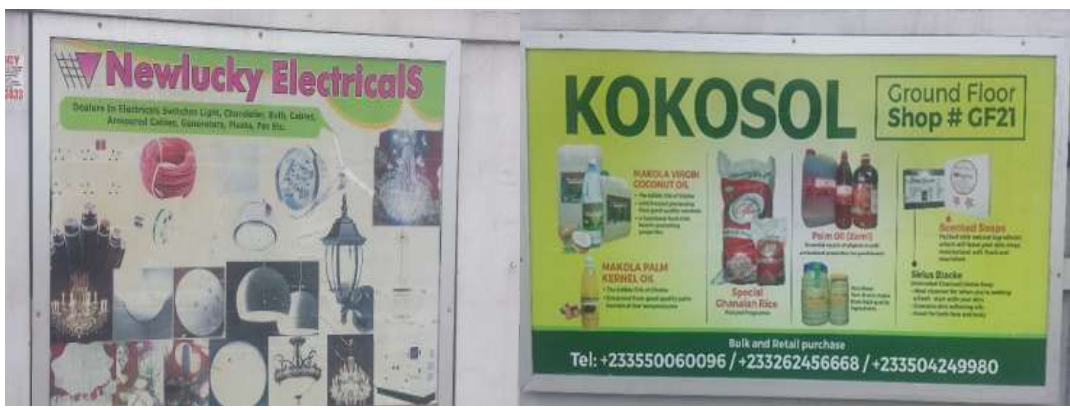

$1 \mathbf{A}$

1B

Figure 1: Coined Categorisation

The second dominant company name form was those that were classified as phrased containing about $19.75 \%$ of the total signage in the sample. This form was dominantly seen among company-based signage. This classification refers to names that had more than one word in its description. It must be noted that signage whose company/brand names were described as phrased had at least two formal words whether in the English language or the Twi language. One bilingual signage appeared under this category. On this sign displayed on a mobile phone retail shop, both Twi and English expressions are identified. As shown in figure 2, the Twi expression adwene $p a$, which is literally translated to mean a good mind, is an adjective that gives an indication of honesty to the customer, while the noun, phone, provides information on the product or service being rendered. 


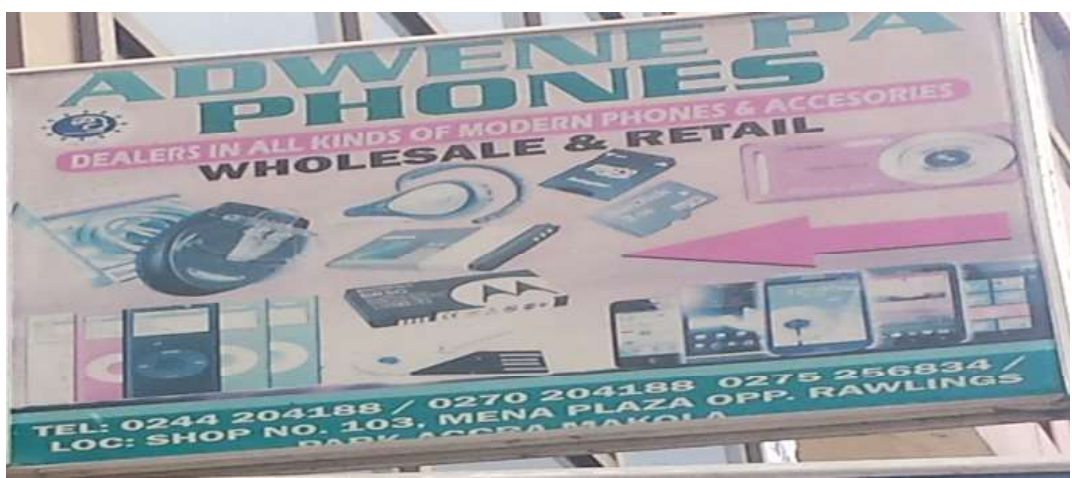

Figure 2: Phrased categorisation (Twi name)

Work detailed categories are described as the category whose name details the kind and the quality of product sold or service rendered. These names can either be coined or phrased. Figure 3 provides the details of a signage named cake accessories. Any customer who sees such a signage gets to understand that the shop or company is into the sale of cake accessories.

Following the phrased classification is the name of person classification which constitutes approximately $17 \%$ of the sample of signage. The name of person classification refers to the signage that contain the proper names of the individuals or groups, usually the owners of the company or the product. These names could either be the name of one person (sometimes given in a full name form such as Nana Asabea Jewellery or abbreviated form such as $M \& G$ Pharmaceuticals or the name of a group (e.g. Three Sisters Forex Bureau). Like the phrased category, the name of person classification is dominantly company based signage. 


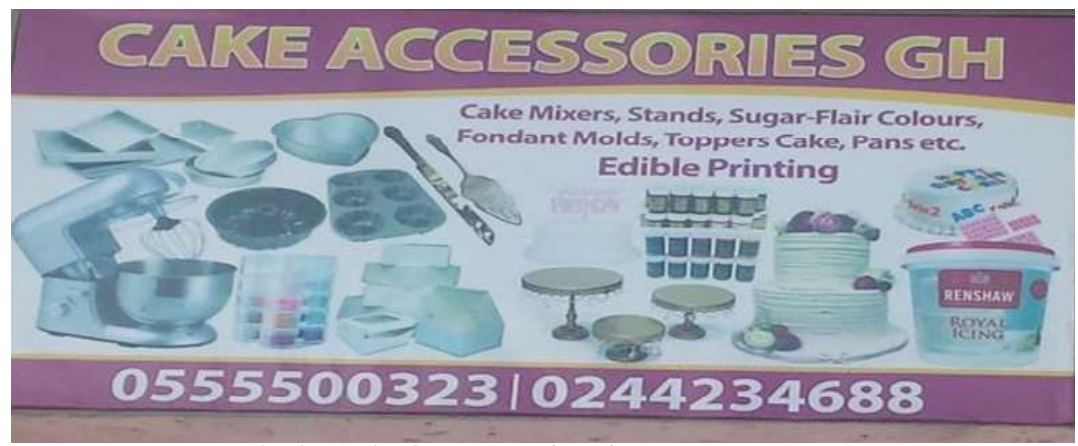

Figure 3: Work detailed categorisation

\section{Analysis of taglines}

Companies, products and services sometimes have taglines that describe the process of their business or the quality of their product or service. The taglines present additional information other than the name of the company and the contact details. About $65 \%$ of the signage had at least one tagline that provided additional information on the product or service.

The use of the Akan language mostly appeared in the taglines of the signage. The Akan-based taglines generally conveyed information that related mainly to beauty, gender and religion. Expressions of beauty were generally contained in hair and beauty products. Figure 4 presents a signage of a skin care product with the tagline ahoof $\varepsilon$ ntoasos that portrays beauty that is endless or timeless. That is to say, a single tagline given in this signage conveys two messages concerning the product; its beauty appeal and its timeless appeal, or the product is known to provide an endless beauty to anyone that uses the product. 


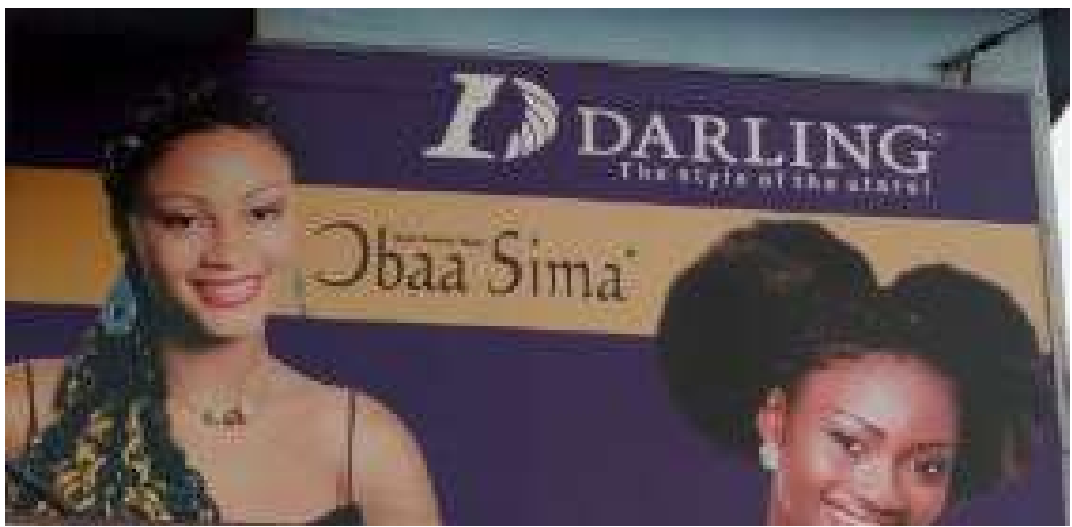

Figure 4: Gender and virtuous woman appeal of a product tagline

Gender related taglines were used also in hair and beauty products generally denoting the idea of a virtuous woman. In both instances of the gender attributes for Akan based signage, the word obaasima meaning virtuous woman was used. Although this does not provide any sense of description to the buyer or passer-by viewing the signage, it portrays two ideas; first the product is to be used by females only and second, any lady that uses the product in one way or another is seen as a virtuous woman, although virtue does not necessarily lie in the choice of skin care product.

Figure 5 highlights the name of a company whose activity is mainly the sale of clothing. The name of the company is presented in a coined word indicated as Nana One which presents an indication of the owner having some level of singularity in the sale of clothing. The tagline presents a connotation of a religious appeal Onyame ne me Boafor translated as God is my helper. This tagline does not present any detail concerning the product or service, but presents the owner of the company or shop as a highly religious individual who finds hope in a higher deity. This same religious appeal is noted in another signage that does not contain any information on product or service description with 
Anderson, J.A., Wiredu, J.F., Ansah, G. N., Frimpong-Kodie, G., Orfson-Offie, E. \& Boamah-Boateng, D./A linguistic landscape of the central business district of Accra

the exception of the display of contacts. This signage bears the name Nhyira translated to mean blessing, connoting the blessing of God or any other deity worshipped by the owner.

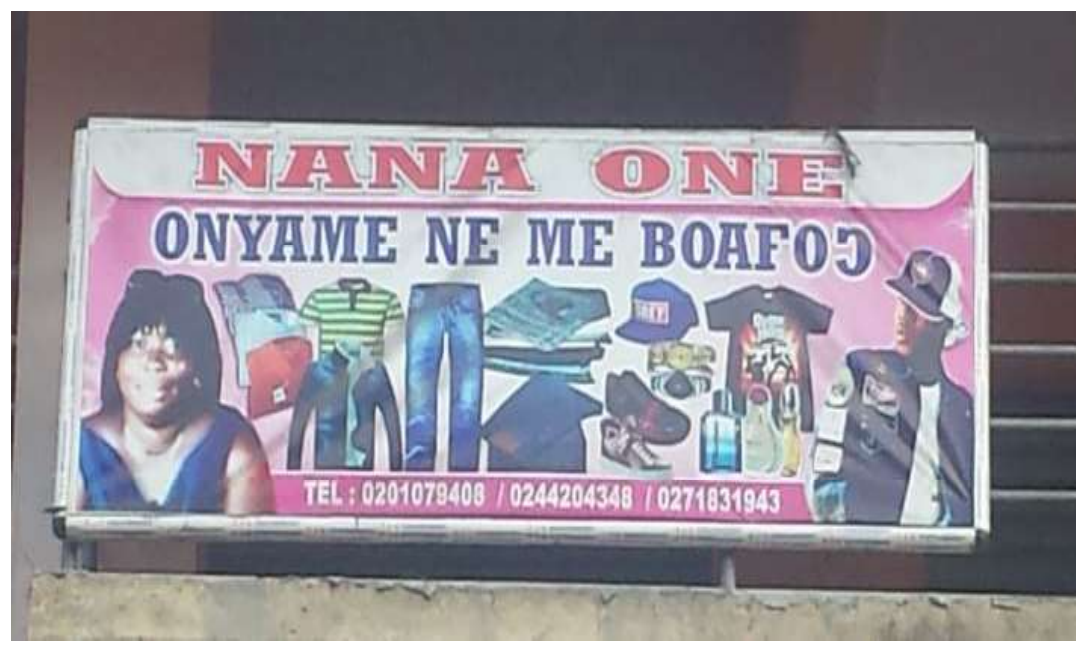

Figure 5: Religious appeal of a Twi language-based signage

In addition to the portrayal of gender, beauty and religion, Akan taglines displayed at one level the use of figures of speech such as simile. Again, this was evident in the products that were related to hair and beauty. Figure 6 presents the signage of a skin care product with a tagline Sokoose TV3 which literally translates as as succulent as TV3. TV3 is a popular television station that started its free to air operations in the late $90 \mathrm{~s}$. The station was famous for its clearer pictures at the time when one compared it to the existing television stations. As a result, in the first two to three years of the $21^{\text {st }}$ century, some sections of Ghanaians described things that are clear to be as clear as TV3. Hence, the expression, Sokoose TV3, highlights the effectiveness of the cream to provide a lighter and a clearer skin, akin to the television station. 


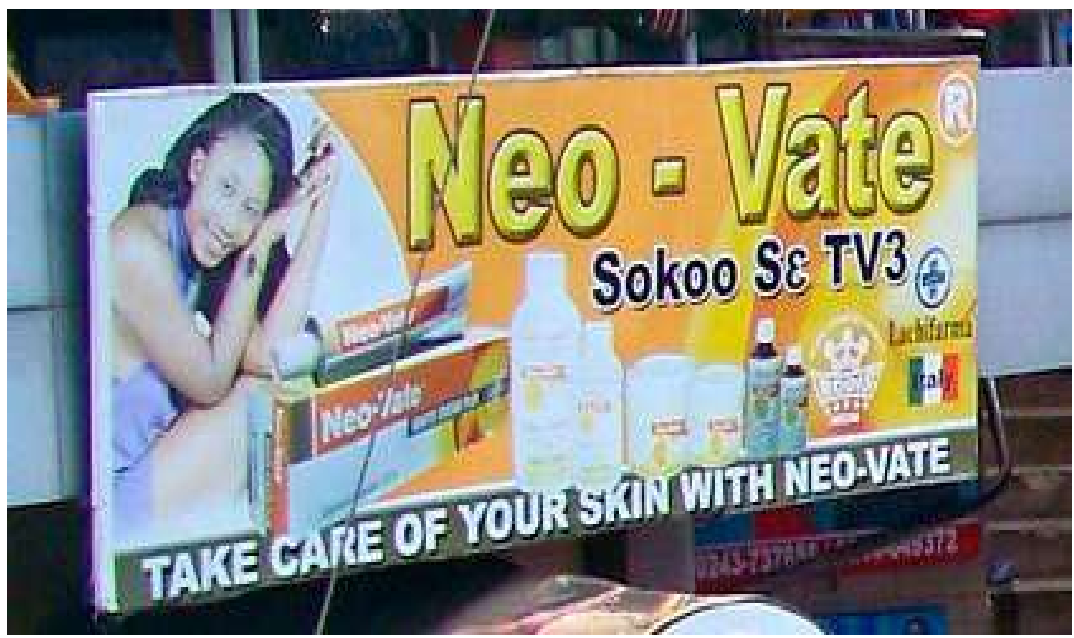

Figure 6: A Bilingual Sign Employing the Use of Simile

English-based taglines, on the other hand, were predominantly geared towards the description of products or services. In addition to the name of the company, the picture of the signage shown in Figure 6 provides details on the products giving additional information to the form of service provided. These are essential, especially in areas where the name of the company or the images provided in the signage do not provide any concrete information on the form of job done by the company. Thus, the onlooker falls on the product description taglines to present an idea of the product which is being sold or the service which is being rendered.

Two forms of product description taglines given in English language emerged. First, there was the product description tagline that focused on describing only the nature of the product sold or service rendered. Second, there is the form of product description tagline that has been qualified with an adjective. For instance, a signage of a vegetable cooking oil described in terms of its quality and health appeal as a cholesterol free oil (see figure 7). Similarly, a beauty product shop whose name and image display does not provide any information on what is sold 
Anderson, J.A., Wiredu, J.F., Ansah, G. N., Frimpong-Kodie, G., Orfson-Offie, E. \& Boamah-Boateng, D./A linguistic landscape of the central business district of Accra

provides a product description tagline which is expressed as quality beauty products and more.

Another variant of the product description appeal given to taglines of purely English based taglines was the use of language in describing sales services. Sales approaches were either used with product description taglines or as a stand-alone tagline. For the former, a shop was described with the tagline wholesale and retail of all kinds of Turkish and Chinese doors. This tagline provides details of the sales posture of the company as they provide both wholesale and retail services in addition to information on the kinds of items that are being sold by the company.

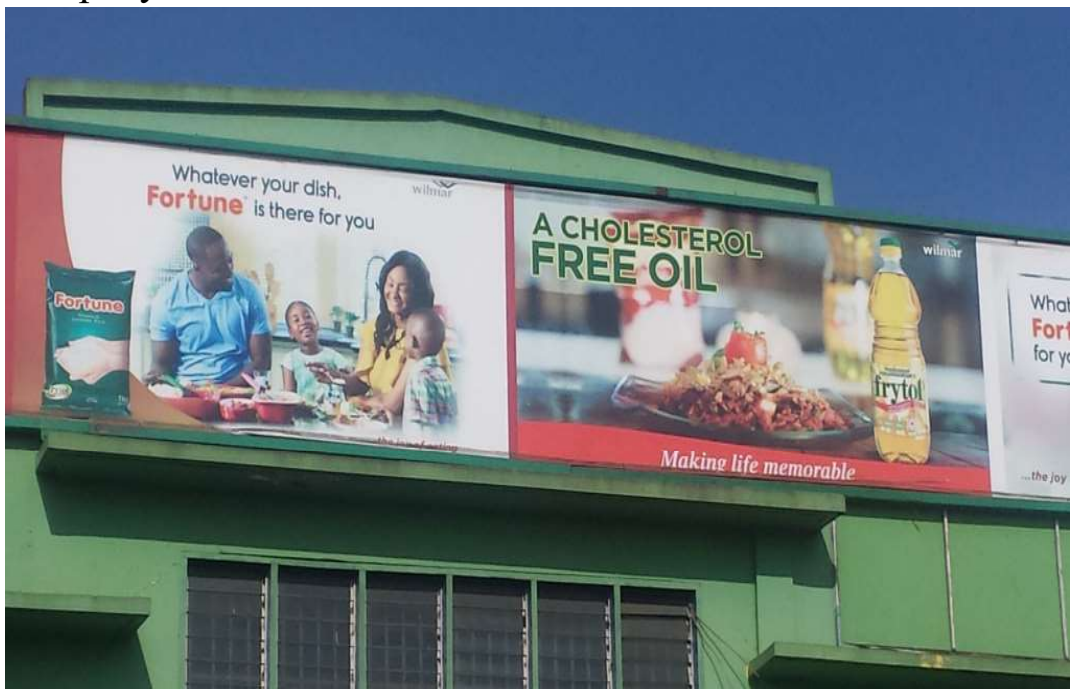

Figure 7: A product describing the quality of a product

\section{English-based taglines versus Twi-Based taglines}

The analysis of the taglines present in the signage outlines some similarities and differences in the use of language in the display of information for the public. The similarities in the taglines are based on the fact that the language used was irrespective of whether the signage bore the information of a 
Anderson, J.A., Wiredu, J.F., Ansah, G. N., Frimpong-Kodie, G., Orfson-Offie, E. \& Boamah-Boateng, D./Legon Journal of the Humanities Vol. 31.1 (2020) particular brand of a product or the name of a company.

In terms of difference in the conveyance of messages using the taglines, there were not much substantial differences between the English-based taglines and the Akan-based taglines. This notwithstanding, differences could be spotted in the forms of messaging carried, for example, in terms of the appeal to a religious deity. From the data gathered, two out of the 12 signage (16\%) containing the Akan language had a religious appeal while the same appeal was captured by only one signage out of 167 signage (less than 1\%) displayed in the English language.

Major differences, however, occurred in the levels of grounding in terms of presenting the taglines on the signage. For the signage that had both English and Akan-based taglines, Twi based taglines were more foregrounded than those of the Englishbased taglines. They were printed in bolder, more highlighted and brighter colours than those of the English language. Figure 8 shows a display of a signage that has both English and Akan language signage, where the Twi inscription Akwaaba meaning welcome is more highlighted and has a bigger font size in comparison with the English language tagline. This tagline had a larger and a bolder font than the name of the company itself. This may indicate that more emphasis is placed on the product than the company that provides the service.

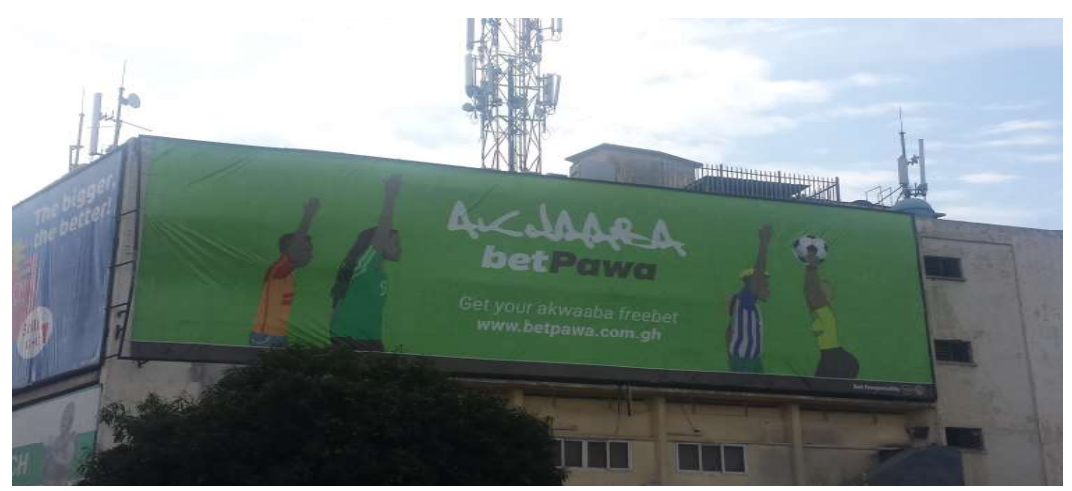

Figure 8: Foregrounding in Twi-based languages 


\section{Discussion}

Our findings present a very busy linguistic landscape. The diversity in the types and content of signage is a reflection of a conscious attempt by shop owners to make a concrete representation of their company and products on the cityscape. Thus, in an attempt to attract customers, shop owners use the names of their company and the products they sell as a marketing strategy through a variety of modes including signboards, billboards, taglines, signposts, etc.

The content of the signage and the representation/ choices of languages offer insights not only about what goes into advertisement in a typical multilingual context, but also an impression about the linguistic vitality and perhaps lack of language planning in this business centre. The first observation one can make in this direction is the word-formation processes that are evident on the signs. These are marks of creativity and a reflection of a lexical gap to map conceptualizations. As is observed from our data, most of the expressions on the signs are blends and clippings of existing English words. It is not surprising that the owners of these signage resort to English predominantly in the formation of these expressions. This has implication for the use of English as an official language of Ghana, for language choices in public spaces in a multilingual Ghanaian context, and for the ethnolinguistic vitality of languages used in this area. Otherwise, one would expect the language of the land, $\mathrm{Ga}$, or the prominent Ghanaian language, Akan, to be resorted to in the creation of these expressions in this market space.

The dominance of English in the signage is another important observation that is worth commenting on. As the language for official transactions in Ghana, English is expected in formal domains. In an informal space like a busy market square, one expects a local language to be used. As has been observed earlier, local languages are normally used in informal and unofficial domains in Ghana. And so, the dominant presence of English in an unofficial domain is an interesting observation 
Anderson, J.A., Wiredu, J.F., Ansah, G. N., Frimpong-Kodie, G., Orfson-Offie, E. \& Boamah-Boateng, D./Legon Journal of the Humanities Vol. 31.1 (2020) of English making incursions into an unexpected space. But this phenomenon makes sense for at least two reasons.

First of all, this observation is a reflection of the special nature of Ghana's multilingual situation. That is, at the official level, Ghana can be considered to be monolingual. This situation, which means that English alone is the language in official domains, has promoted the culture where written documentation is done predominantly in English at the neglect of local languages. As a result, many Ghanaians can only speak their local language. That is, they lack the ability to read and write in their local language. This may have accounted for the dominance of the English language in the signage in the marketing centre, taking the signage as a form of written documentation. The implication is that writing in Ghana is done predominantly in English regardless of the domain; an observation that is worth investigating in other areas.

The second implication about the dominance of English in this Ghanaian marketing centre is that this particular space is a melting pot of several cultures, tongues and ethnicities. Thus, English is the most neutral language for a context such as this. This means that the shop owners are aware of the variegated background of their prospective clients and so communicate with them through the language that the majority will understand. This also has an implication for the linguistic vitality of English in Ghana as the dominant language not only for written documentation but also for national cohesion due to its neutrality.

According to the Place Semiotics Theory by Scollon and Scollon (2003), the position of a particular language on a bilingual or multilingual sign, as well as salient characteristics of signs such as the font style, font colour, and font size may contribute to the importance attached to a particular language. The study revealed that on bilingual signs featuring both English and Twi, the Twi language was given more prominence by being printed in bolder, more highlighted and brighter colours. In fact, 
the presence of Twi on bilingual signs and its position on these signs highlight the important role the Twi language performs in Ghana and makes it a very important indigenous language in the country. It is worth noting that business owners in this busy market are aware of the influence of Akan in this market. As a result, Akan is the alternative language besides English for branding companies and for taglines. As has been noted earlier, Akans in Accra are more than Gas in Accra. Thus, it makes economic sense for business owners to target Akan speaking patrons since, as noted earlier, Akan has more second language speakers than any other local language in Ghana.

\section{Conclusion}

According to Landry and Bourhis (1997), "Public signs can be unilingual, bilingual or multilingual, thus reflecting the diversity of the language groups inhabiting the territory in question" (p. 26). On the surface, the linguistic landscape of Accra appears to be multilingual considering the presence of Twi and Ga. However, as noted by Reyes (2014) in his work in Philippines, it is more appropriate to consider the situation as unilateral because of the overwhelming prevalence of English on the signs. The dominance of English in the linguistic landscape of Accra corroborates the findings of studies conducted by Reyes (2014), Shibliyev (2014), Koschade (2016), Loth (2016), Zimny (2017), and Lusekelo and Alphonce (2018).

Indeed, the linguistic landscape of Accra underlines the value placed on the English language in the country. Nevertheless, it also exposes the apparent low vitality of the indigenous languages. In a situation like this, some language planning is necessary. In order to increase the vitality of $\mathrm{Ga}$, at least, on its autochthonous territory, a simple bilingual requirement may be enforced according to which shops and companies in marketing centres in Accra will be made to translate aspects of signage into the local language of the land. 
Anderson, J.A., Wiredu, J.F., Ansah, G. N., Frimpong-Kodie, G., Orfson-Offie, E. \& Boamah-Boateng, D./Legon Journal of the Humanities Vol. 31.1 (2020)

\section{References}

Adebola, A. (2017). Analysis of elements of Africanism in the Nigerian linguistic landscape. International Journal of Linguistics and Communication. 5(1), 35-43. DOI: 10.15640/ijlc.v5n1a4

Akindele, D. O. (2011). Linguistic landscapes as public communication: A study of public signage in Gaborone, Botswana. International Journal of Linguistics 3(1). 1-11.

Alomoush, O. I. (2015). Multilingualism in the linguistic landscape of urban Jordan. (Doctoral Thesis). University of Liverpool, Liverpool, UK.

Backhaus, P. (2007). Linguistic landscapes: A comparative study of urban multilingualism in Tokyo. Clevedon: Multilingual Matters.

Banda, F. \& Hambaba, J. (2015). The semiotic ecology of linguistic landscapes in rural Zambia. Journal of Sociolinguistics, 19(5): 643-670.

Cenoz, J. \& Gorter, D. (2006). Linguistic landscape and minority languages, International Journal of Multilingualism (special issue), 3 (1), (6780). Retrieved from http://dx.doi.org/10.1080/14790710608668386

Curriculum Research Unit, Ghana Education Service (1996). Change-The Impact of Training Colleges on Ghanaian Schools. Accra Ghana, Accra (p.43)

Dako, K. (2000). Pidgin as a gender specific language in Ghana. Ghanaian Journal of English Studies, 1, 73 - 82.

Dako, K. \& Quarcoo, M. (2017). Attitudes towards English in Ghana. Legon Journal of the Humanities. 28. 20. 10.4314/ljh.v28i1.3.

Dakubu, M. E. K. (1997). Korle Meets the Sea, a Sociolinguistic History of Accra. New York: Oxford University Press.

Dakubu, M. E. K. (2009). The historical dynamic multilingualism in Accra. In McLaughlin, F (ed.), The Languages of Urban Africa, 19.

Dixson, A. E. (2015). Analyzing the Multilingual Linguistic Landscape of Buffalo, New York. (Doctoral Thesis). State University of New York, Fredonia, New York.

Du Plessis, L. T. (2012). The role of language policy in linguistic landscape changes in a rural area of the Free State Province of South Africa. Language Matters: Studies in the Languages of Africa, 43 (2), 263 282.

Edelman, L. (2010). Linguistic landscapes in the Netherlands: A study of multilingualism in Amsterdam and Friesland. Leiden: LOT.

Edmund, L. J. (2017). An evolving mainstream: a linguistic landscapes analysis of migration and assimilation in Cary, NC. Second Language Studies, 35(2), 31-64.

Essegbey, J. (2009). On assessing the ethnolinguistic vitality of Ga in Accra. The languages of urban Africa, 115, 130.

Legon Journal of the Humanities 31.1 (2020) 
Anderson, J.A., Wiredu, J.F., Ansah, G. N., Frimpong-Kodie, G., Orfson-Offie, E. \& Boamah-Boateng, D./A linguistic landscape of the central business district of Accra

Fekede, A. \& Gemechu, T. (2015). An analysis of linguistic landscape of selected towns in Oromia: An ethnolinguistic vitality study. Journal of Languages and Culture. 7(1), 1-9. Retrieved from DOI: 10.5897/JLC2015.0329

Ghana Statistical Service, (2012). 2010 Population and housing census. Accra: Sakoa Press Limited

Giles, H., Bourhis, R. Y. \& Taylor, D. M. (1977). Towards a theory of language in ethnic group relations. In Howard Giles (ed.), Language, ethnicity and intergroup relations, 307-348. London: Academic Press.

Huber, M. (1999). Ghanaian Pidgin English in its West African Context. Amsterdam: John Benjamins.

Koschade, A. (2016). Willkommen in Hahndorf: A Linguistic Landscape of Hahndorf, South Australia. International Journal of Humanities and Cultural Studies ISSN 2356-5926

Kotze, C. \& Du Plessis, T. (2010). Language visibility in the Xhariep a comparison of the linguistic landscape of three neighbouring towns. Language Matters, 41(1): 72-96.

Landry, R. and Bourhis, R.Y. (1997) Linguistic landscape and ethnolinguistic vitality: An empirical study. Journal of Language and Social Psychology, 16 (1), 23 49.

Loth, C. R. (2016). The linguistic landscape as construct of the public space: a case study of post-apartheid rural South Africa. (Doctoral dissertation). University of the Free State, South Africa Lusekelo, A. \& Alphonce, C. (2018). The linguistic landscape of urban Tanzania: An account of the language of billboards and shop-signs in district headquarters. Journal of Language, Technology \& Entrepreneurship in Africa. Vol.9. No.1.

Pavlenko, A. (2010). Linguistic landscape of Kyiv, Ukraine: A diachronic study. In Shohamy, Ben-Rafael \& Barni, (Eds.), pp. 133-150.

Reyes, R. A. (2014). Language of 'order': English in the Linguistic Landscape of Two Major Train Stations in the Philippines. Asian Journal of English Language Studies (AJELS) Volume 2.

Said, I. G. \& Rohmah, Z. (2018). Contesting Linguistic Repression and Endurance: Arabic in the Andalusian Linguistic Landscape. Pertanika Journal of Social Sciences \& Humanities, 26(3), 18651881.

Scollon, R. \& Scollon, S. W. (2003). Discourses in place: Language in the material world. London: Routledge.

Shibliyev, J. (2014). Linguistic landscape approach to language visibility in post-soviet Baku. Bilig, 71, 205.

Shohamy, E. \& Gorter, D. (Eds.) (2009). Linguistic landscape: expanding the scenery. London and New York: Routledge.

Legon Journal of the Humanities 31.1 (2020) 
Anderson, J.A., Wiredu, J.F., Ansah, G. N., Frimpong-Kodie, G., Orfson-Offie, E. \& Boamah-Boateng, D./Legon Journal of the Humanities Vol. 31.1 (2020)

Spolsky, B. \& Cooper, R. (1991). The languages of Jerusalem. Oxford:

Clarendon Press.

Spolsky, B. (2009). Prolegomena to a sociolinguistic theory of public

signage. In E. Shohamy \& D. Gorter (Eds.), Linguistic landscape:

Expanding the scenery (pp. 25-39). New York, NY: Routledge.

Yagmur, K. \& Kroon, S. (2003). Ethnolinguistic Vitality

Perceptions and Language Revitalisation in Bashkortostan.

Journal of Multilingual and Multicultural Development. Retrieved

from DOI: 10.1080/01434630308666504

Zimny, D. (2017). Language and Place-Making: Public Signage in the

Linguistic Landscape of Windhoek's Central Business District.

(Unpublished M. A. Thesis). Stellenbosch University, South Africa.

\section{Appendix \\ The coding structure}

The pictures selected were coded in order to bring meaning into the analysis of data. The coding structure for the present study was adapted from Edelman (2010). Changes in the coding structure were made to reflect contextual peculiarities among Ghanaian signages. This section highlights the various variables that were coded for the analysis of the study and the explanations and categories to each variable are explained below. A summary is presented in Table (1).

1. Identity: This variable presents a unique identification number to each of the pictures. Each picture was preceded by a prefix that identified the geographic area of the signage in addition to a unique identification number $M A$ was assigned to all pictures taken at Accra Central.

2. Area: This is a categorical variable that outlined the area the pictures were taken (Accra Central).

3. Signage form: This variable describes whether the signage presents information of a company or a brand. There are four main categories highlighted in this variable; signages of companies, signages that show products, signages that show a blend of products and companies, and signages that show government programs.

4. Establishment type: the type of establishment was identified

Legon Journal of the Humanities 31.1 (2020)

Page $\mid 31$ 
Anderson, J.A., Wiredu, J.F., Ansah, G. N., Frimpong-Kodie, G., Orfson-Offie, E. \& Boamah-Boateng, D./A linguistic landscape of the central business district of Accra

as either shops, religious institutions, banking and financial institutions or product advertisement.

5. Sector: this variable identified the various areas or sectors that the signages were based on. Examples include mother care shops, technology and communication, education services, beauty and cosmetics.

6. Industry Chain: The industry chain variable measures whether the signage is that of an independent company, a national brand or a global brand. Most brands of products in Ghana are independently owned, but there are others that are owned by government and transcends across the national boundaries. In addition, global brands refer to products or companies that are located across the world (for e.g. Samsung).

7. Number of languages: This variable, which is numeric in nature, presents the number of languages that are present on the signage.

8. Multilingualism: This variable christened multilingualism sub categorises the number of languages variable. All signages with a single language were categorized as monolingual while signages with more than one language were categorized as multilingual.

9. Language: This variable displays all the languages used on the signage.

10. Dominance in font: This indicates whether information on the signages is presented in the same fonts and styles or the words are written in the same font sizes and styles. This is to reflect the level of emphasis placed on some words, and language within the signage.

11. Dominant font: This section highlights areas in the signage that had the dominant font. These could be in the form of the company or product name, a part of the company / product name, the description of product or company, or the taglines.

12. Dominance description: This provides further clarity on where the dominance in terms of fonts is applied to the 
Anderson, J.A., Wiredu, J.F., Ansah, G. N., Frimpong-Kodie, G., Orfson-Offie, E. \& Boamah-Boateng, D./Legon Journal of the Humanities Vol. 31.1 (2020)

signage. The variable indicates whether the dominance in the signage was presented in its title or generally in the description of product or service or the tagline.

13. Dominant language: This variable highlights the language in which the dominance in font size or style was shown. This is important particularly for multilingual signages.

14. Presence of translation: this variable was to describe whether languages in multilingual signages were translations of each other. For instance, whether a word written in English was translated to a different language on the same signage.

15. Company name style: Various company or product names have different ways of naming and language plays a major role in this. This variable highlights the various ways companies or products were named.

16. Meaning of company name:This variable attempts to provide meaning to the companies or products. It presents an idea of what signal the name sends to an onlooker.

17. Language of tagline: Signages of products and companies mostly have taglines that serve as a motto or presents additional information to the company or product. This variable presents a description of the language of such taglines used in the signages.

18. Meaning of tagline: this variable provides meaning to the taglines provided on the signages.

19. Remark: This variable captures other information and other special characteristics of the signages. 
Anderson, J.A., Wiredu, J.F., Ansah, G. N., Frimpong-Kodie, G., Orfson-Offie, E. \& Boamah-Boateng, D./A linguistic landscape of the central business district of Accra

Table (1): Coding structure for the study

\begin{tabular}{|c|c|c|}
\hline Variable name & Description & \begin{tabular}{|l|}
$\begin{array}{l}\text { Categories } \\
\text { variable }\end{array}$ \\
\end{tabular} \\
\hline ID & $\begin{array}{l}\text { Provides a unique } \\
\text { identification to } \\
\text { signages } \\
\end{array}$ & Open ended \\
\hline Area & $\begin{array}{l}\text { Geographical area of } \\
\text { signages }\end{array}$ & 1. $\begin{array}{l}\text { Accra Central } \\
\text { (Makola) }\end{array}$ \\
\hline Sign Form & Form of signage & 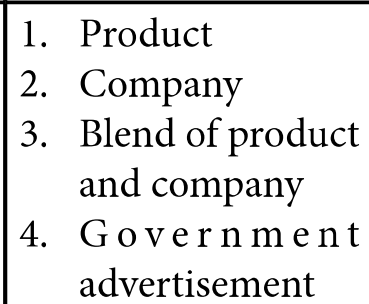 \\
\hline Est_Type & $\begin{array}{l}\text { Type of } \\
\text { establishment }\end{array}$ & Open ended \\
\hline Sector & $\begin{array}{l}\text { Sector within which } \\
\text { establishment is } \\
\text { found }\end{array}$ & Open ended \\
\hline Ind_chain & Industry chain & $\begin{array}{ll}\text { 1. In d e p e n d e n t } \\
\text { chain } \\
\text { 2. National chain } \\
\text { 3. Regional chain } \\
\text { 4. Global chain } \\
\end{array}$ \\
\hline Lang_num & $\begin{array}{l}\text { Number of languages } \\
\text { on signage }\end{array}$ & Numeric \\
\hline Mult_level & $\begin{array}{l}\text { Whether signage } \\
\text { is monolingual or } \\
\text { multilingual. }\end{array}$ & 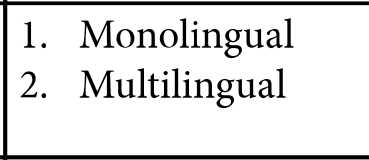 \\
\hline Lang & \begin{tabular}{|l|}
$\begin{array}{l}\text { Language used in } \\
\text { signage }\end{array}$ \\
\end{tabular} & Open ended \\
\hline Lang_font & $\begin{array}{l}\text { Dominance of } \\
\text { language in fonts }\end{array}$ & \begin{tabular}{|ll} 
1. & Yes \\
2. & No \\
\end{tabular} \\
\hline
\end{tabular}

Legon Journal of the Humanities 31.1 (2020) 
Anderson, J.A., Wiredu, J.F., Ansah, G. N., Frimpong-Kodie, G., Orfson-Offie, E. \& Boamah-Boateng, D./Legon Journal of the Humanities Vol. 31.1 (2020)

\begin{tabular}{|l|l|l|}
\hline Dom_font & $\begin{array}{l}\text { Description of } \\
\text { dominance }\end{array}$ & Open ended \\
\hline Dom_descr & $\begin{array}{l}\text { Further description } \\
\text { of dominance }\end{array}$ & $\begin{array}{l}\text { 1. Title } \\
\text { 2. Description }\end{array}$ \\
\hline Dom_Lang & $\begin{array}{l}\text { Language of } \\
\text { dominance }\end{array}$ & Open ended \\
\hline Translation & $\begin{array}{l}\text { Presence or absence } \\
\text { of translation }\end{array}$ & $\begin{array}{l}\text { 1. Present } \\
\text { 2. Absent }\end{array}$ \\
\hline Comp_name & $\begin{array}{l}\text { Company or product } \\
\text { name style }\end{array}$ & $\begin{array}{l}\text { 1. Phrased } \\
\text { 2. Name of person } \\
3 . \text { Stylised } \\
4 . \text { Abstract }\end{array}$ \\
\hline $\begin{array}{l}\text { Comp_name } \\
\text { meaning }\end{array}$ & $\begin{array}{l}\text { Meaning of company } \\
\text { or product name }\end{array}$ & Open ended \\
\hline Lang_tagline & Language of tagline & Open ended \\
\hline $\begin{array}{l}\text { T a g 1 i n e } \\
\text { meaning }\end{array}$ & Meaning of tagline & Open ended \\
\hline Remark & $\begin{array}{l}\text { Other special } \\
\text { characteristic about } \\
\text { signage }\end{array}$ & Open ended \\
\hline
\end{tabular}

